\title{
Impact of Digitalization on the Farmers in India: Evidence using Panel Data Analysis
}

\author{
Rahul Singh Gautam, Venkata Mrudula Bhimavarapu, Shailesh Rastogi
}

\begin{abstract}
The composition of digitalization and financial technology has brought about a new development model for the agriculture sector. What is the impact of digitization on India's farmers? To answer this issue, this article examines the effects of digitalization on farmers in India using secondary data from 2018 to 2020, based on the idea of digitalization. It analyses the transmission of digitalization among Indian farmers using panel data analysis. The conclusions are as follows: Farmers' income can be significantly increased by digitalization, and farmers' digitization has resulted in agriculture sector development and contributed to economic progress.
\end{abstract}

Keywords: Digitalization, Agriculture Sector, Formers, Financial Inclusion, Banking, KCC, GVA, NSVA.

\section{INTRODUCTION}

$\mathrm{D}$ igitalization is a technique that allows everyone to participate in and profit from economic progress; India pioneered digitalization by nationalizing its banks in mid1969 and then enacting a slew of laws to put it in place [66]. Agriculture sector people who live at BoP in the economy, these people move through digitalization and financial technology. At the bottom of the pyramid, the agriculture sector people are the highest, also the poorest socioeconomic group. And digitalization is a key factor in this sector's rapid expansion of Increasing agricultural development and growing farmer incomes are critical [73]. Digitalization substantially minimizes the risk of households being in extreme poverty. Digitalization will compensate for the head of a household's lack of formal education to some degree. Even with limited access to electricity, digitalization continues to have a significant impact on poverty, and financial inclusion is strengthened and targeted at poor households, particularly poor women-owned households in rural areas. Digitalization influences customer financial behavior, and it is directly linked to financial literacy. The percentage of awareness of digitalization has increased after financial literacy showing a direct effect of financial literacy on inclusion.

Manuscript received on September 05, 2021.

Revised Manuscript received on September 08, 2021.

Manuscript published on September 30, 2021.

* Correspondence Author

Rahul Singh Gautam, Ph.D. Scholar, Symbiosis Institute of Business Management, Pune; Symbiosis International (Deemed University), Pune, India.Email: bouddhrahul@gmail.com

Venkata Mrudula Bhimavarapu*, Ph.D. Scholar, Symbiosis Institute of Business Management, Pune; Symbiosis International (Deemed University), Pune, India. Email: mrudulabhimavarapu@gmail.com

Dr. Shailesh Rastogi, Professor, Symbiosis Institute of Business Management, Pune; Symbiosis International (Deemed University), Pune, India.Email: krishnasgdas@gmail.com

(C) The Authors. Published by Blue Eyes Intelligence Engineering and Sciences Publication (BEIESP). This is an open access article under the CC BY-NC-ND license (http://creativecommons.org/licenses/by-nc-nd/4.0/)

The adoption of digitalization has simplified the branch authorization, increase in rural areas and digitalization embraces environmental credit, Positive change in the Financial transaction has been made easy for rural people [9]. financial literacy is the most important social welfare microfinance and suitable development and its positive impact on BOP people. The most important is financial knowledge to rural people and financial training for the best result of financial inclusion [22]. Digitalization can remove corruption and fraud, and agricultural people can seed their Aadhaar with their bank accounts, and government benefits can give directly to bank accounts [66]. Digitalization has played the most important role in economic growth, and the government stable the microfinance bank and community banks in rural areas to reach unbanked people and financial products and services need to decrease their charges, and here is a need to aware rural people benefit of financial inclusion [40]. The success of digitalization provides the banking services affordable cost for the low-income group, and here most important requirement of commercial banks is bank branch expansion in rural areas, and aware rural people for the financial literacy, credit counseling, KKC/GCC mobile banking, micro insurance, microcredit, the bank should have provided simple and affordable product and services for high utility [49],[1]. The benefits of digitalization bring better transparency, scalability, and accountability and stop fake currency, terrorist and it will help to hold back black money and RBI and the government are also promoting a digital payment system, mobile wallet, ine recharge, online ticket booking, and promote $\mathrm{E}$ commerce, and the government also launched the UPI payment system [57]. The cash market day by day changes in the digital market and growth the digital banking sector, nd most people adopt the cashless economy and digita saving. It helps to make easy transactions records [29]. The concept of a cashless society to take steps of capacity building of people, improve banking and digital infrastructure and any society use less cash and day by day mostly use digital payment system, and cashless economy it means less use of cash mostly transaction of funds by debit card credit card, digital payment method [41]. Digitalization reduces poverty, and it is affected overall economic growth but can increase inequality [2]. The government of India and the Reserve Bank of India have been promoting offers to improve digital financial inclusion, and the digital inclusion concept can be realized by developing awareness programs about digital financial inclusion, developing business strategies for financial institutions, and providing financial services to low-income groups.[19],[67].

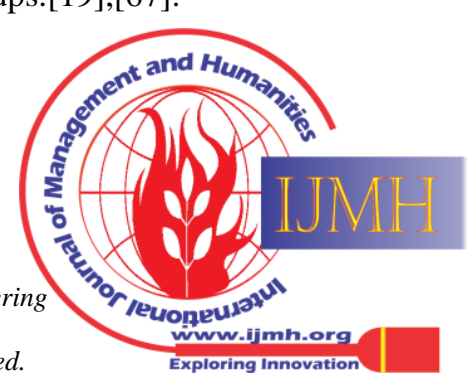




\section{Impact of Digitalization on the Farmers in India: Evidence using Panel Data Analysis} impact of digitization on the formers. Digitalization is a critical component of an economy's economic development; it will change the face of agriculture in the future, providing better profits for farmers and minimize harm [78],[73]. The studies focus on the impact of digitalization in the agriculture sector in India. The major motivation for this study is the critical need for a situation study assessment and the lack of any studies in this area. Because of the following reasons, we chose to investigate the impact of digitalization on Indian farmers utilizing evidence and a panel data analytic approach: The unobserved variables are seen in panel data analysis, which aids in detecting the cumulative influence of cause on the output while also accounting for reciprocal covariance and The behavioral elements of digitization and its influence on Indian farmers are better captured by panel data analysis than by traditional econometric or regression analysis. As a result, it was chosen to employ panel data analysis in the model. The purpose of this article is to investigate the impact of digitalization on Indian farmers. The rest of this paper is organized as follows. After the introduction, the next section is Theoretical background building in the article. And the third section is a relevant literature review and hypothesis formulation on digitalization on the formers in India. The fourth section presents the data and methodology. The fifth section presents the results of the study. The sixth section is a discussion of the results. And the last section has been the conclusion of the study.

\section{THEORETICAL BACKGROUND}

Financial Inclusion (FI) is defined as any effort to bring unbanked people to the main stream by facilitating them with the banking services or formal credit system [61],[64]. There is evidence to prove that FI helps in improving the quality and standard of life as well [30],[11],[61],[50],[3],[68]. In India farmers are supposed to stay in far-flanged places where lack of basic financial services and poverty are rampant [77],[39],[21]. FI obviously also caters to them in more than one ways [26]. The impact of FI on the well-being of unbanked people, poor people or rural people is well documented [69],[60],[31],[71],[70],[4],[58]. However, the impact of digitalization in the financial services and its impact is relatively less researched area [62],[59]. There are many initiatives across the world, including in India to bring technology to the forefront of unbanked people so that they may get benefited [50],[45]. The additional challenge in bringing the technology to the forefront of the unbanked people is ease of use and cost [14],[20]. In India, Open Banking provides a workable solution to the problem in bringing technology to the unbanked people successfully [63],[62],[60]. This study is aimed at assessing the impact of technology (digitalization in financial services) on the wellbeing of the farmers. The impact of Financial Inclusion is not limited to the well-being of the unbanked people. Whereas it affects the stock market [51],[52],[53]. corporate action policies of the corporate (Pinto et al., 2019, Pinto and Rastogi, 2019) and even corporate governance policies of the firms [69],[70],[10].
In India, no research has been conducted to assess the

\section{REVIEW OF LITERATURE AND HYPOTHESES FORMULATION}

The literature on the topic covers the digitalization of Indian farmers to how it contributes to the resolution of agricultural development challenges. The formers' social influence as a result of digitalization. The literature on the topic, on the other hand, is piecemeal and does not give a holistic and cause-and-effect link of digitization of formers, as the current study provides. The goal of this literature study is to look into the link between farmers and digitalization. Digital banking is the provision of inexpensive banking facilities to a wide range of disempowered and low-income people [27]. Digitalization has an effect on a country's economic development and many other initiatives [32]. In this article, digitalization can be improved when the financial benefit is clearly addressed [12]. This study expresses that digitalization is a powerful instrument for farmers' development. According to further study, Other demographic characteristics such as education level, household income, age demographic, and amount of farmland are related to digitalization [33]. in this research, the drivers of digitalization include digital banking addressing financial services and financial literacy; People's behavior in terms of financial purchases has been influenced by the affected of demonetization [61]. Digitalization is a multi-layered notion that requires a comprehensive strategy that considers everything from fundamental financial needs to the use of technical resources to make financial services more efficient [15]. Financial inclusion will increase income flow and reduce poverty throughout the economy [16]. People are encouraged to invest and save more as a result of digitalization, which acts as a driver for the economy's massive growth [46]. Digitalization is an important component of an economy's economic development, but it does have an impact on public financial services [68]. The policy is becoming increasingly important for digitalization in many nations, including India. Bank preferences, internet banking, Mobile Banking, and Digital money have all been identified as influential variables in the successful implementation of the system [64]. Digitization may help foster high and sustainable development; it will transform the face of the Agriculture sector in the future, ensuring higher profit for farmers and reducing harm [73]. Digitalization can assist impoverished fishing people and rural populations in minimizing their risks and enhance their financial [24]. Privately, especially in combination with online banking, digitalization can boost economic performance. It is necessary to invest in teaching individuals about the use of ICT in formal commercial banks [17]. In this research, India's digitalization rose by 0.045 points on the average IFI, and digitalization is influenced by a number of factors, including the proportion of agriculture in a state's gross domestic product, literacy rates, size of the population, capacity building, and agricultural deaths [78].

Blue Eyes Intelligence Engineering \& Sciences Publication 
Digitalization availability can considerably decrease the rural-urban earnings difference amongst those aspects, and among the indicators of digitalization, digitalization can relieve the urban-rural income inequality via the transmission mechanism of promoting citizens' entrepreneurial ventures; the worse the economic growth and prosperity and education, the greater the effect of digitalization on the urban-rural wealth disparity, the worse the economic growth and prosperity and education the greater the effect of digitalization on the urban-rural wealth disparity [28]. this study expresses that Gujarat's Akodara Village is recognized as the "first Indian digital village." The ICICI Bank sponsored this Village and transformed it into a fully digital village with appropriate infrastructure, guiding the Village toward online transactions, and he says digitalization is the need of the era [66]. Household debt has such a substantial bad influence on agricultural development in Pakistan in both the short and long run, according to this study, whereas wide money and cropped area have a positive impact in both situations, and Agriculture output is favorably correlated with digitalization [23]. H1: Digitalization impacts the agriculture sector. The study looked at agricultural GDP (AGDP), government financing, the agricultural credit guarantee scheme fund (ACGSF), and credit, mortgages, and advances given to the rural agricultural sector by commercial banks. The goal of this study was to determine the impact of agricultural finance on agricultural achievements to Nigeria's economic growth. They used research that spanned the years 1981 to 2016, Agribusiness and A Commercial banks' loans, mortgages, and loans to the agricultural sector had a strong and large impact on the agricultural share of GDP government financing, and CGSF had a non-significant impact [75]. This research expressed that, digitization of impoverished farmers, rural non-farm enterprises, and other disadvantaged population is critical for improving living circumstances, and the involvement of self-help organizations and microfinance institutions is critical for promoting financial inclusion [21]. This study expressed that microfinance effective tool for poverty-reducing and achieve digitalization, and this research is used secondary data NABARD, GoI, RBI, etc. [21]. This study demonstrates how important digitalization is for the agriculture sector and its promotion; digitalization improves agricultural commercialization, according to the Heckman treatment effect model [5]. The importance of terms of cost efficiency in Africa's financial system is reflected in the fact that the connection between informal and formal financial intermediation is complementary rather than competitive, using formal financial brokers decreases the desire to keep cash, suggesting that a well-developed financial system network has the potential to mobilize excess cash in Africa's informal sector for growth and development, formal digitalization is positively correlated with informal banking services [6]. Digitalization is now recognized to be far implications that can help many individuals escape poverty. Significant investments in financial education, the development of public service offerings, the improvement of delivery systems, and the inclusion of services such as credit, remittance, and financial advising services may all help to achieve significant and successful progress [76]. In Nigeria, digitalization in the agriculture sector is still quite low. It was suggested, including other things, that the government increase its efforts to satisfy the financial needs

of the rural in order to promote digitalization [34]. The study revealed that digitalization had a significant influence on poverty reduction among small and marginal farmers using begression method, conducting financial literacy campaigns among farmers since these characteristics are crucial in affecting farmers' involvement in financial inclusion or prohibiting them from doing so [42]. Regarding India's rising economic prominence and estimates that the Indian economy would be as big as the US economy by 2050, microfinance is an equalizer that allows all citizens to participate in and benefit from economic progress [35]. The government of India \& RBI has out with a major initiative so that the access of financial services will reach mass population. Financial inclusion denotes the of financial services at an affordable cost to the vast sections of the disadvantaged and low-income groups, and Inclusive growth is not possible without financial inclusion 43]. In this study, family expenses, literacy, religion, place shown to be reliable characteristics affecting family digital payments levels. This might lead to much organization, which could enhance farm families' livelihoods [44]. Only if

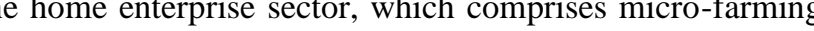
development would it be feasible. A banking sector it does affect service home firms will not support sustainable development; instead, access to finance of family businesses will only contribute to sustainable development if it can be increased [36]. The government promoting this digital saction system provide offers to move to the digital pystem and most important is the development of decreasing poverty rate especially rural woman constrained by financial services together non-financial services including with skill and entrepreneurial and affordable financial services, especially credit open up the poor and bank Ghana to add the unbanked people with the bank [24]. The bank is promoting financial inclusion, and financial inclusion can break properly various cercal of poverty implemented, and RBI creates a conducive environment for oor people and India needs to improve the rural financial system and financial literacy and economic stability for economic growth [37]. These findings, based on bank and survey data, suggest that agency banking rules and financial acy might help Kenya enhance formal access to finance [38]. Nations rank differently in the Economic Ranking and the Education Development Score. Nations that rank high in education fare badly in economic development, implying at in countries with similar economic development, academic performance is often bad as well, implying that rising financial inclusion and improving educational outcomes for continuous economic development are both [7]. This study makes use of both primary and secondary data. The information was gathered from 16 different bank branches.

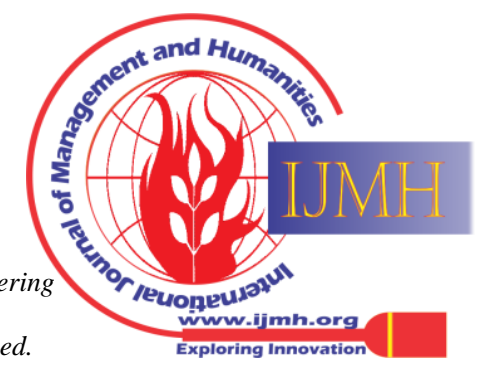




\section{Impact of Digitalization on the Farmers in India: Evidence using Panel Data Analysis}

Though the number of ATMs has greatly grown, microfinance has accelerated even in rural regions, indicating that banks have directly led to accessing the unserved people; low literacy, in that order, is considered by so many banks as a key obstacle to financial inclusion [47]. This study expresses that, In India, NBFC-MFIs are inefficient in terms of financial efficiency. Companies' financial viability may be enhanced by improving their technological productivity. Businesses should also improve their operations [70]. H2: The link between digitization and farmers is mediated through financial inclusion. Financial inclusion significantly reduces the likelihood of reducing poverty in households. Increasing financial inclusion and targeting poor families, especially those living in farmer-led rural areas led by poor women [19]. The most important is financial knowledge to rural people, and there is a need for financial training for the best result of financial inclusion [22]. barriers to financial inclusion such as lack of money, distance, fixed cost, and documentations are important obstacles in Ethiopia [13]. financial development has a positive effect on digital economy transformation and financial inclusion on economic transformation is the most impact in Nigeria, financial is most important on economic transformation, and it helps to terminate poverty in Nigeria [3]. financial inclusion can affect overall economic growth thereby reducing poverty but can increase inequality and inequality has a positive and significant impact on poverty in Indonesia [2]. financial inclusion in Nigeria and enhanced business-friendly environment, financial innovation, mobile capacity, and robust financial education [8]. The success of mobile money depends on whether the solution moves away from the paradigms used for designing mobile money solutions for those at the top of the pyramid [18]. Educational age has appositive relation with Financial Literacy while Education level is not associated with Financial Literacy and married women have a lower level of financial literacy relative to single women while working women have a higher level of financial literacy than selfemployed women in the case of work [72]. the Banks, NGOs, and SHGs are achieving social inclusion, and the government and RBI promote the digital transaction to reduce the transaction cost [48]. The adoption of the FI has simplified the branch authorization, increase in rural areas and do FI embraces environmental credit, Positive change in the behavior of unbanked people FL increases Financial transaction has been made easy for rural people [9].

Table 1. Descriptive

\begin{tabular}{ccccc}
\hline SN & Mean & SD & Min & Maximum \\
\hline GVA (Lac) & $57,73,433$ & $64,62,596$ & 39,922 & $2.50^{*} 10^{7}$ \\
NSVA (Lac) & $52,12,604$ & $59,92,010$ & 21,368 & $2.48 * 10^{7}$ \\
KKC_n & $21,801.51$ & $26,69,463$ & 4000 & $1.20^{*} 10^{7}$ \\
KKC_a (Lac) & $21,78,084$ & $27,05,864$ & 1560 & $1.13^{*} 10^{7}$ \\
\hline
\end{tabular}

\section{RESULTS}

In order to determine whether the model should use a Model 1 (fixed-effect) and Model 2 (Random effect), we first performed the F-test, and the results showed that we should use a fixed-effect model, and then we added individual and time dual control effects. To avoid endogeneity, the average growth rate of the Kisan Credit Card (KCC) and Gross value added (GVA) a dependent variable.
The benefits of a cashless economy many people move to the digital mode for saving their time and easy transaction, traceable, and hold black money. The high cash currency circulation in India and 95\% of transactions being cash, mostly ATM use for cash windrow [65]. the cash market day by day changes in the digital market and growth the digital banking sector, and most people adopt in the cashless economy and digital transaction more than safe cash transactions and time-saving. It helps to make transaction records [29]. easily; most people are not using the digital transaction system because they were not aware of this system, Financial inclusion in Uttar Pradesh and Bihar state we found the expansion of bank branches has not reached the internal part of undeveloped states which is most important for awareness of financial inclusion education [56]. financial inclusion provide banking services at an affordable cost for the low-income group and here most important requirement of commercial banks is, bank branch expansion in rural areas and aware rural people for financial literacy, credit counseling, KKC/GCC mobile banking, micro insurance, microcredit, the bank should have provided simple and affordable product and services for high utility [49]. H3: The link between formers and agricultural progress is mediated by trust.

\section{DATA AND METHODOLOGY}

This study uses secondary data collected from RBI. The RBI website has an accurate and comprehensive directory of states and banks that are regulated by the RBI. The data has been taken from major states of India for three years (from FY 2018 to 2020). There are several examples in the literature when the measure, GVA, NSVA, and Number of KCC, and amount of KCC, respectively, are used. In this study, the same method is used. (Table 1. Descriptive) The relationship is established using panel data econometrics. The unit root test is performed on all four variables utilized in this study before running the panel data models to ensure that the data is stationary. Because panel data econometrics is commonly used in studies of states, banks, and their performance, the same established technique is used in this work [2],[1],[3],[31]].

The statistical values of each variable are shown in Table 1. 
Table 2. Static Panel Data Results (For Gross)

\begin{tabular}{|c|c|c|c|c|}
\hline & \multicolumn{2}{|c|}{ Model 1 (Fixed Effect) } & \multicolumn{2}{|c|}{ Model 2 (Random Effect) } \\
\hline & DV: GVA & DV: GVA (Robust) & DV: GVA & $\begin{array}{l}\text { DV: GVA } \\
\text { (Robust) }\end{array}$ \\
\hline Constant & $68,36,192$ & $68,36,192$ & $15,91,490$ & $15,91,490$ \\
\hline KKC_n & $-.4875 *, .2235(.051)$ & $\begin{array}{l}-.4875, .5835 \\
(.410)\end{array}$ & -- & -- \\
\hline KKC_a & -- & - & $\begin{array}{l}1.9200, .2004 \\
(.0000)\end{array}$ & $\begin{array}{l}1.9200, .2881 \\
(.0000)\end{array}$ \\
\hline F-test (Model) & $3.91 * *(.0524)$ & $.7000(.410)$ & $91.73(.0000)$ & $44.43(.0000)$ \\
\hline R-Square & .0603 & .0603 & 1837 & 1837 \\
\hline$\sigma_{\text {vit }}$ & $27,06,809.6$ & $27,06,809.6$ & $33,84,940.10$ & $33,84,940.10$ \\
\hline F-test Fixed Effect & $32.39(.0000)$ & $32.39(.0000)$ & $50.54(.0000)$ & $50.54(.0000)$ \\
\hline Theta & -- & -- & .8616 & .8616 \\
\hline Breush-Pagan Test & $51.52(.0000)$ & $51.52(.0000)$ & $82.29(.0000)$ & $82.29(.0000)$ \\
\hline Hausman Test & $41.53(.0000)$ & $41.53(.0000)$ & $1.10(.2939)$ & $1.10(.2939)$ \\
\hline No of observations (n) & 93 & 93 & 93 & 93 \\
\hline Degree of freedom & & & & \\
\hline Wald test for Heteroscedasticity ${ }^{1}$ & $7.70 * 10^{10}(.0000)$ & $7.70 * 10^{10}(.0000)$ & $1.0 * 107(.0000)$ & $1.0 * 107(.0000)$ \\
\hline $\begin{array}{l}\text { Wooldridge Autocorrelation } \\
\text { Test }^{2} \text { AR (1) }\end{array}$ & $5.849(.0219)$ & $5.849(.0219)$ & $7.5880(.0099)$ & $7.5880(.0099)$ \\
\hline
\end{tabular}

We first only considered the univariate impact of digitalization on the formers in India, then added Exploratory variables for regression, and finally used dependent variables, as shown in Table 2. The results show that in both model 1 (Fixed Effect) and model 2 (Random Effect), Model 1 (Fixed Effect), the coefficient of Kisan Credit Card (Number of Kisan Credit Card) is negative and significant at the $5 \%$ level and Model 2 the coefficient of Kisan Credit Card (Number of Kisan Credit Card) is not a correlation with the gross value added (GVA), and F-test (Model) significant at the $10 \%$ level. This shows that the Kisan credit card does not correlate with gross value added (GVA). Table 2 also shows that Kisan credit card (KCC) has a poor effect on gross value added (GVA). The impact of Kisan Credit Card on gross value added (GVA) is not significant, which indicates that the importance of Kisan Credit Card (KCC) cannot be replaced by traditional finance.

\section{Table 3. Static Panel Data Results (For Net)}

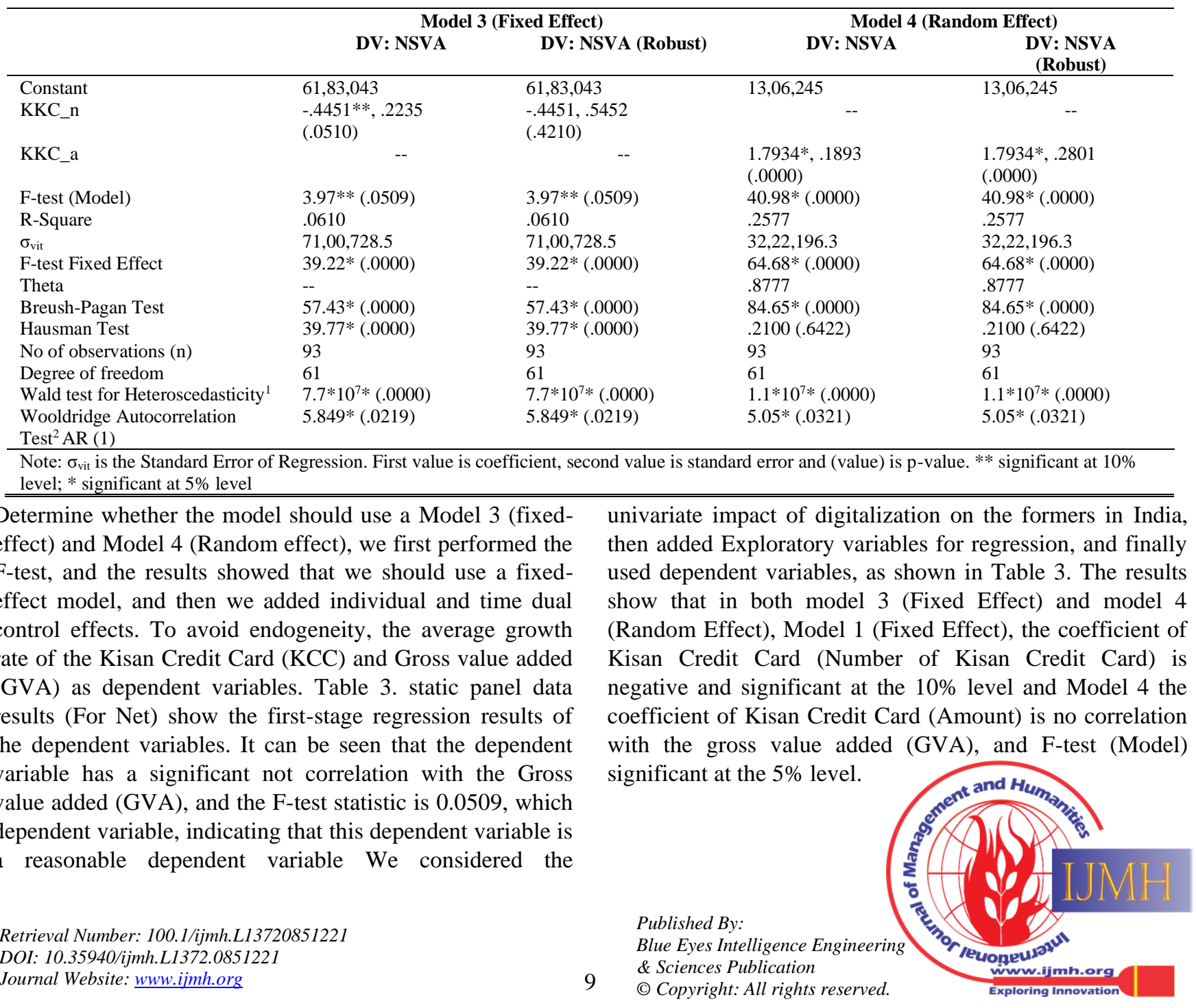




\section{Impact of Digitalization on the Farmers in India: Evidence using Panel Data Analysis}

This shows that the Kisan credit card does not correlate with gross value added (GVA). Table 3 also shows that Kisan credit card (KCC) has a poor effect on gross value added (GVA). The impact of Kisan Credit Card on gross value added (GVA) is not significant, which indicates that the importance of Kisan Credit Card (KCC) cannot be replaced by traditional finance.

\section{DISCUSSION}

We should keep pushing for digitization to progress. We should focus on expanding the coverage of digitalization, give priority to solving the shortcomings of insufficient financial inclusion coverage, and on this basis, continue to strengthen the depth of its use and the degree of digitalization, to provide more diverse and efficient digitalization to agricultural people. The government should give adequate financial assistance, enhance local Internet infrastructure building, increase public awareness initiatives, and encourage rural inhabitants to embrace digitization. Digitization may help foster high and sustainable development; it will transform the face of the Agriculture sector in the future, ensuring higher profit for farmers and reducing harm [73]. Digitalization can help disadvantaged rural residents reduce their risks and improve their financial [24]. Digitalization is now widely acknowledged to have far-reaching effects that can assist many people in escaping poverty. Considerable expenditures in financial education, the creation of public service offerings, the strengthening of delivery infrastructure, and the inclusion of services like credit, remittance, and financial advising services might all contribute to significant and successful growth [76].

\section{CONCLUSION}

The integration of digitalization and financial technology provides average support for resolving farmer's growth. Its inclusive development concept will help farmers to avail the digitalization they deserve, thus playing a role in poverty reduction and increase of the farmers in India. Based on the secondary data (RBI) from the financial year 2018 to 2020, this paper explores the impact of digitalization on the formers in India. This paper found that digitalization can significantly increase the growth of farmers' income and digitalization of the farmer only the expansion of coverage can reduce the formers poverty gap substantially. The convergence effect of digitalization on the farmers in India is better with lower levels of economic development, reflecting its inclusive nature.

\section{REFERENCE}

1. Abel, B. B. (2018), "Financial Inclusion in Burundi: The Determinants of Loan-Taking Motivation in Semi-Rural Areas," Int. Jr. of Organizational Innovation, Vol. 11 No. 1, pp. 1-14.

2. Anwar, A.I., \& Amrullah, A. (2017), "Impact of Financial Inclusion towards Poverty in Indonesia. Advances in Economics", Business and Mgmt. Research, Vol. 40 No. 2, pp. 407-410.

3. Adeola, O. \& Evans, O. (2017), "Financial inclusion, financial development, and economic diversification in Nigeria," The Jr. of Developing Areas, Vol. 51 No. 3, pp. 1-15.

4. Athaley, C., Rastogi, S., Goel, A. \& Bhimavarapu, V. (2020), “Factors Impacting Bank's Performance: A Literature Review," Test Engineering and Mgmt., Vol. 83 No. May-June, pp. 7389-7398.

5. Abu, B. M., \& Haruna, I. (2017), "Financial inclusion and agricultural commercialization in Ghana: an empirical investigation," Agricultural Finance Review, Vol. 77 No. 4, pp. 524544.

6. Alhassan, A., Li, L., Reddy, K., \& Duppati, G. (2019), "The impact of formal financial inclusion on informal financial intermediation and cash preference: evidence from Africa," Applied Economics, Vol. 51 No. 42, pp. 4597-4614.

7. Arora, R. U. (2012), "Financial inclusion and human capital in developing Asia: The Australian connection," Third World Quarterly, Vol. 33 No. 1, pp. 177-197.

8. Aro-Gordon, S. (2016), "Implementation of financial inclusion strategy in Nigeria," SDMID Jr. of Mgmt., Vol. 8 No. 2, pp. 27-43.

9. Bhagwan, P. (2019), "Empirical Study on Relationship Between Financial Inclusion and Financial Literacy and Its Impact on Consumer Financial Behaviour: A Theoretical Framework of Unbanked People," Jr. of Commerce \& Accounting Research, Vol. 8 No. 1, pp. 61-67.

10. Bhimavarapu, V. M. \& Rastogi, S. (2020), "Valuation of Transparency-A Systematic Literature Review Paper," Test Engineering and Mgmt., Vol. 83 No. May-June, pp. 9092-9102.

11. Bucci, A., La Torre, D., Liuzzi, D. \& Marsiglio, S. (2019), "Financial contagion and economic development: An epidemiological approach", Jr. of Economic Behavior \& Organization, Vol. 162 No. June 2019, pp. 211-228.

12. Bhanot, D., Bapat, V., \&Bera, S. (2012), "Studying financial inclusion in north-east India," Int. Jr. of Bank Marketing, Vol. 30 No. 6, pp. 465-484.

13. Baza, A.U., \& Rao, K.S. (2017), "Financial Inclusion in Ethiopia," Int. Jr. of Economics and Finance (IJEF), Vol. 9 No. 4, pp191-201.

14. Collard, S. (2007), "Toward financial inclusion in the UK: Progress and challenges," Public Money and Mgmt., Vol. 27 No. 1, pp. 13-20.

15. Cnaan, R. A., Moodithaya, M. S., \& Handy, F. (2012), "Financial inclusion: lessons from rural south India," Jr. of Social Policy, Vol. 41 No. 01, pp. 183-205.

16. Chauhan, S. (2014), "Access to finance in Madhya Pradesh: An exploratory study," Indian Jr. of Commerce and Mgmt. Studies, Vol. 5 No. 2, pp. 8-17.

17. Chatterjee, A. (2020), "Financial inclusion, information and communication technology diffusion, and economic growth: a panel data analysis," Information Technology for Development, Vol. 26 No. 3, pp. 607-635.

18. Chavan, A.L., Arora, S., Kumar, A., \& Reddy, P. (2009), "How Mobile Money can Drive Financial Inclusion for Women at the Bottom of the Pyramid (BOP) in Indian Urban Centres," Springer, Berlin, Heidelberg, Vol 5623, No. July, pp. 475-484. https://doi.org/10.1007/978-3-642-02767-3_53.

19. Dawood, T. C., Pratama, H., Masbar, R., \& Effendi, R. (2019), "Does financial inclusion alleviate household poverty? Empirical evidence from Indonesia”, Economics \& Sociology, Vol. 12 No. 2, pp. 235-252.

20. Dev, S. M. (2006), "Financial inclusion: Issues and challenges," Economic and political weekly, Vol. 41 No. 41, pp. 4310-4313.

21. Dev, S. M. (2006), "Financial inclusion: Issues and challenges," Economic and political weekly, Vol. 41, No. 41 (Oct. 14-20, 2006), 4310-4313.

22. Emmanuel, M., \& Masaru, Y. (2014), "Microfinance for The Urban Bottom of The Pyramid Segment in Nairobi's Kibera Slum in Kenya: Does Financial Training Impact on Sustainable Urban Development?", African Jr. of Sustainable Development, Vol. 4 No. 1, pp. 1-15.

23. Farooq, U., Gang, F., Guan, Z., Rauf, A., Chandio, A. A., \& Ahsan, F. (2021), "Exploring the long-run relationship between financial inclusion and agricultural growth: evidence from Pakistan," International Journal of Emerging Markets, Vol. 0434 No. 06, pp. 120.

24. Frimpong, A., \& Mensah, R.O. (2020), "Financial Inclusion Among Rural Households in Ghana," Jr. of Economics and Sustainable Development, Vol. 11 No. 4, pp. 182-190.

25. Goel, R., Sahai, S., Vinaik, A., \& Garg, V. (2019), "Moving from Cash to Cashless Economy: - A Study of Consumer Perception Towards Digital Transactions," Int. Jr. of Recent Technology and Engineering (IJRTE), Vol. 8 No. 1, pp. 1220-1226.

26. Jawed Akhtar, S. M. \& Alam, M. M. (2017), "Financial Inclusion in India: An Analysis of SHG--Bank Linkage Programme," Finance India, Vol. 31 No. 1, pp. 279-288.

Blue Eyes Intelligence Engineering \& Sciences Publication

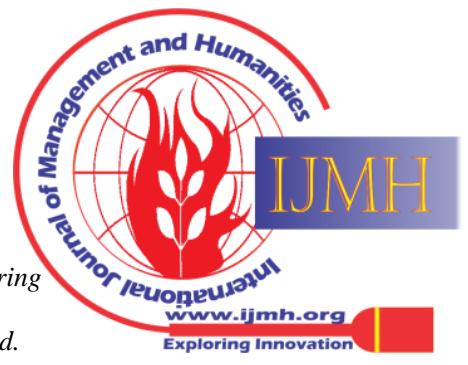


27. Joshi, M., \&Rajpurohit, V. P. (2016), "Awareness of Financial Inclusion: An Empirical Study," Int. Jr. of Multidisciplinary, Vol. 1 No. 6, pp. 1-6.

28. Ji, X., Wang, K., Xu, H., \& Li, M. (2021), "Has Digital Financial Inclusion Narrowed the Urban-Rural Income Gap: The Role of Entrepreneurship in China," Sustainability, Vol. 13 No. 15, pp. 8292.

29. Kumar, P. (2015), "An Analysis of Growth Pattern of Cashless Transaction System," Int. Jr. of Research in Business Mgmt. (IMPACT: IJRBM), Vol. 3 No. 9, pp. 37-44.

30. Kavya, T. \& Shijin, S. (2020), "Economic development, financia development, and income inequality nexus," Borsa Istanbul Review, Vol. 20 No. 1, pp. 80-93.

31. Kuknor, S. \& Rastogi, S. (2021), "DETERMINANTS OF PROFITABILITY IN INDIAN BANKS: A PANEL DATA ANALYSIS," Int. Jr. of Modern Agriculture, Vol. 10 No. 2, pp. 978 986.

32. Kumar, N. (2013), "Financial inclusion and its determinants: evidence from India,” Jr. of Financial Economic Policy, Vol. 5 No. 1, pp. 4-19.

33. Kumar, A., \& Gupta, H. (2019), "Financial Inclusion and Farmers Association between Status and Demographic Variables," Vol. 8 No. 4, pp. 5868-5879.

34. Kalu, U. I., Omeje, A. N., \& Mba, A. J. (2018), "Financial inclusion in the agricultural sector in Nigeria: An index of penetration," Int Jr.of Economics and Financial Issues, Vol. 8 No. 5, pp. 35.

35. Kapoor, A. (2014), "Financial inclusion and the future of the Indian economy,” Futures, Vol. 56 No. February, pp. 35-42.

36. Kasekende, L. (2014). What Role Does Financial Inclusion Play in the Policy Agenda for Inclusive Growth in Sub-Saharan Africa?", Development, Vol. 57 No. 3, pp. 481-487.

37. Kaur, P. (2014), "A Study on Financial Inclusion - Role of Indian Banks in Implementing A Scalable and Sustainable Financia Inclusion Strategy," Int. Jr. of Mgmt. (IJM), Vol. 5 No. 11, pp. 103 110.

38. Kodongo, O. (2018), "Financial regulations, financial literacy, and financial inclusion: Insights from Kenya," Emerging Markets Finance and Trade, Vol. 54 No. 12, pp. 2851-2873.

39. Lalrinmawia, M. \& Gupta, H. (2015), "Literacy and Knowledge: Farmers' Financial Inclusion Feasibility," SCMS Journal of Indian Mgmt., Vol. 12 No. 3, pp. 17-24.

40. Michael, O. B., \& Sharon, O. O. (2014), "Financial system, financial inclusion and economic development in Nigeria," Int. Jr. of Mgmt. Sciences, Vol. 2 No. 3, pp. 139-148.

41. Maurya, P. (2019), "Cashless Economy and Digitalization," SSRN Electronic Journal, Risbank, pp. 710-715. https://doi.org/10.2139/ssrn.3309307.

42. Mhlanga, D., Dunga, S. H., \& Moloi, T. (2020), "Financial inclusion and poverty alleviation among smallholder farmers in Zimbabwe," Eurasian Jr. of Economics and Finance, Vol. 8 No. 3, pp. 168-182.

43. Mamatha, M. (2015), "Financial Inclusion-Initiative by RBI," Int. Jr of Research and Computational Technology, Vol. 7 No. 3, pp. 1-15.

44. [44] Mohammed, F., Barrowclough, M. J., Kibler, M. L., \& Boerngen, M. A. (2020), "Measuring usage of formal financial services as a proxy for financial inclusion: A case of agricultura households in Ghana," Agricultural Finance Review, Vol. 80 No. 4 , pp. 471-489.

45. Niebel, T. (2018), "ICT and economic growth-Comparing developing, emerging and developed countries," World Development, Vol. 104 No. April, pp. 197-211.

46. Nair, M. S. (2015), "Financial Inclusion vis-à-vis Economic Efficiency: The Case of Commercial Banks in India," Productivity, Vol. 55 No. 4, pp. 338-345.

47. Nkuna, O., Lapukeni, A. F., Kaude, P., \& Kabango, G. (2018), “The role of commercial banks on financial inclusion in Malawi," Open Jr. of Business and Mgmt., Vol. 6 No.04, pp. 812-832.

48. Noronha, M., \& Kumar, V. R. (2019), "Technology: A Tool for Achieving Inclusive and Sustainable Growth Through Financia Inclusion," Clear International Jr. of Research in Commerce \& Mgmt., Vol. 10 No. 2, pp. 1-5.

49. Parashar, Y. (2016), "Financial Inclusion in India: Role of Banks," Int. Research Jr. of Commerce Arts and Science, Vol. 7 No. 2, pp. 84-88.

50. Palvia, P., Baqir, N. \& Nemati, H. (2018), "ICT for socio-economic development: A citizens' perspective," Information \& Mgmt., Vol. 55 No. 2, pp. $160-176$

51. Patil, A. C. \& Rastogi, S. (2019), "Time-Varying Price-Volume Relationship and Adaptive Market Efficiency: A Survey of the Empirical Literature," Jr. of Risk and Financial Mgmt., Vol. 12 No. 2, pp. 1-18.
52. Patil, A. C. \& Rastogi, S. (2020a), "Multifractal Analysis of Market Efficiency across Structural Breaks: Implications for the Adaptive Market Hypothesis," Jr. of Risk and Financial Mgmt., Vol. 13 No. 10, pp. 1-18.

53. Patil, A. C. \& Rastogi, S. (2020b), "Multifractal Analysis of TimeVarying Market Efficiency: Implications for Adaptive Market Hypothesis," Test Engineering and Mgmt., Vol. 83 No. May-June pp. 16646-16660.

54. Pinto, G. \& Rastogi, S. (2019), "Sectoral Analysis of Factor Influencing Dividend Policy: Case of an Emerging Financial Market," Jr. of Risk and Financial Mgmt., Vol. 12 No. 3, pp. 110.

55. Pinto, G., Rastogi, S., Kadam, S. \& Sharma, A. (2019) "Bibliometric study on dividend policy," Qualitative Research in Financial Markets, Vol. 12 No. 1, pp. 72-95.

56. Pandey, A., \& Raman, R. (2012-13), "Financial Inclusion in Uttar Pradesh and Bihar," Prajnan, Vol. 41 No. 2, pp. 125-146.

57. Roopadarshini, S., \& Lakshminarayana, K. (2018), "A Study on Impact of Cash Less Transaction on The Indian Economy," Int. Jr. of Advanced in Mgmt., Technology and Engineering Sciences, Vol. 8 No. 1, pp. 340- 349.

58. Rastogi, S. (2011), "Impact of Currency Futures on Spot Market Volatility: An Empirical Study," Vidwat: The Indian Jr. of Mgmt., Vol. 4 No. 2, pp. 3-8.

59. Rastogi, S., Goel, A. \& Doifode, A. (2020a), "Open API in Indian banking and economic development of the poor: opportunities and challenges," Int. Jr. of Electronic Banking, Vol. 2 No. 4, pp. 321 348.

60. Rastogi, S., Gupte, R. \& Meenakshi, R. (2021a), "A Holistic Perspective on Bank Performance Using Regulation, Profitability, and Risk-Taking with a View on Ownership Concentration,” Jr. of Risk and Financial Mgmt., Vol. 14 No. 3, pp. 1-19.

61. Rastogi, S. \& Ragabiruntha, E. (2018), "Financial inclusion and socio-economic development: gaps and solution," Int. Jr. of Social Economics, Vol. 45 No. 7, pp. 1122-1140.

62. Rastogi, S., Sharma, A. \& Panse, C. (2020b), "Open Banking and Inclusive Growth in India," Indian Jr. of Ecology, Vol. 47 No. SI9, pp. 75-79.

63. Rastogi, S., Sharma, A., Panse, C. \& Bhimavarapu, V. M. (2021b), "Unified Payment Interface (UPI): A Digital Innovation and Its Impact on Financial Inclusion and Economic Development," Universal Jr. of Accounting and Finance, Vol. 9 No. 3, pp. 518-530.

64. Rastogi, S., Suresh, V. \& Leonard, D. (2017), "FINANCIAL INCLUSION AND DEMONETIZATION: AN EMPIRICAL STUDY USING EXPLORATORY FACTOR ANALYSIS," Indian Jr. of Commerce and Mgmt. Studies, Vol. 8 No. 1(5), pp. 38-46.

65. Rao, S.R., \& Naresh, S. (2017), "Challenges and Prospects of Cashless Economy in India," International Journal \& Magazine of Engineering, Technology, Management and Research, Vol. 4 No. 10, pp. 304-309.

66. Saxena, D., \& Joshi, N. (2019), "Digitally Empowered Village: Case of Akodara in Gujarat, India," South Asian Jr. of Business and Mgmt. Cases, Vol. 8 No. 1, pp. 27-31.

67. Singh, C., \& Naik, G. (2017), "Financial inclusion in India: A case study of Gubbi," IIM Bangalore Research Paper, Vol.549 No. May, pp. 549, 1-69.

68. Sehrawat, M. \& Giri, A. (2016), "Financial development and poverty reduction in India: an empirical investigation," Int. Jr. of Social Economics, Vol. 43 No. 2, pp. 106-122.

69. Sharma, A. \& Rastogi, S. (2021), "Impact of Efficiency on Voluntary Disclosure of Non-Banking Financial CompanyMicrofinance Institutions in India," Jr. of Risk and Financial Mgmt., Vol. 14 No. 7, pp. 289-311.

70. Sharma, A., Rastogi, S. \& Gupta, N. (2020), "Financial Efficiency of Non-Banking Financial Companies-Microfinance Institutions: A Data Envelopment Analysis," Test Engineering and Mgmt., Vol. 83 No. May-June 2020, pp. 9080-9091.

71. Singh, I. \& Rastogi, S. (2020), "Drivers impacting bank risk in India," Test Engineering and Mgmt., Vol. 83 No. May-June, pp 8005-8011.

72. Shanti, S., \& Murty, A.V.N. (2019). The Impact of Financial Literacy on women in Several Districts of Andhra Pradesh", Int. Jr. of Recent Technology and Engineering (IJRTE), Vol. 8, No. 1S4, pp. 901-906.

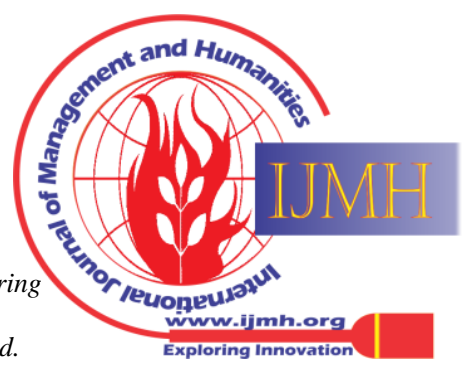


73. Upadhayay, M. (2019). Digitalization of agriculture in India: challenges and hopes", Int. Jr. of Innovative Social Science \& Humanities Research, Vol. 6 No. 1, pp. 5-11.

74. Varghese, J. J., Sharma, D., \& Singh, N. K. (2019), "Analysing the impact of blockchain technology in India's digital economy," Global Jr. of Enterprise Information System, Vol. 11 No. 1, pp. 94-99.

75. Victor, N., EU, O. O., \& Kabiru, B. (2019), “AGRIC FINANCING AND ITS IMPACT ON AGRICULTURAL GDP: AN ARDL APPROACH," Int. Jr. of Sustainable Agricultural Research, Vol. 6 No. 1, pp. 47-60.

76. Varghese, G., \& Viswanathan, L. (2018), "Normative perspectives on financial inclusion: Facts beyond statistics," Jr. of Public Affairs, Vol. 18 No. 4, pp. 1829.

77. Yeung, G., He, C. \& Zhang, P. (2017), "Rural Banking in China: Geographically Accessible but Still Financially Excluded?", Regional Studies, Vol. 51 No. 2, pp. 297-312.

78. Yadav, P., \& Sharma, A. K. (2016), "Financial inclusion in India: an application of TOPSIS," Humanomics

\section{AUTHORS PROFILE}

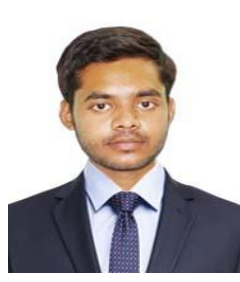

Rahul Singh Gautam, is currently pursuing a Ph.D. as a full-time research scholar at SIBM Pune Constitution of Symbiosis International (Deemed University). He is an MBA (Finance) from the Dr. Shakuntala Mishra National Rehabilitation University, Lucknow, and MPhil in Financial Management from Babasaheb Bhimrao Ambedkar University (A Central University), Lucknow. He has around 3 years of experience in the field of research. (bouddhrahul@gmail.com)

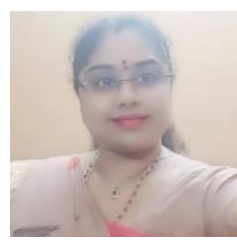

Venkata Mrudula Bhimavarapu, currently pursuing Ph.D. as a full-time research scholar a Symbiosis International (Deemed University). She is an MBA gold medallist from Andhra University and MPhil in Financial Management from Annamalai University. She has around 7 years of experience in the field of academics and research. She has presented papers at national-level conferences. (mrudulabhimavarapu@gmail.com)

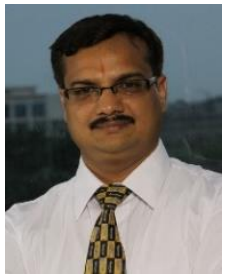

Shailesh Rastogi, is presently working as a professor at SIBM Pune. He has more than 20 years of experience of academics and industry. His areas of expertize include conducting MDPs on Panel Data Econometrics, Financial Econometrics, Financial Analytics using spreadsheet \& V.B. and Corporate Valuation. He is a prolific researcher and has more than 70 research papers published in the national and (krishnasgdas@gmail.com) international journal of repute

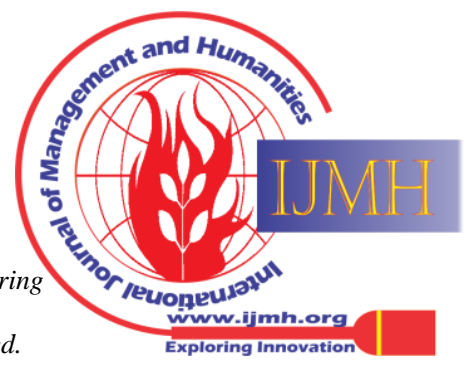

